\title{
The Effect of Addition of Avocado Fruit Seeds On Bioplastic Biodegradation
}

\author{
Viki Fathurohman, Darmawan Alisaputra*, Endaruji Sedyadi \\ Department of Chemistry, Faculty of Science \& Technology, UIN Sunan Kalijaga. \\ Email*: alidarmawan982@gmail.com
}

\begin{abstract}
Bioplastics can be made with chitosan as a base material with a sorbitol plasticizer and avocado-based seed starch. This study tries to discuss the comparison of avocado seeds to bioplastic biodegradability required based on weight loss in soil media. This research was carried out in empathic, namely making avocado starch, making bioplastics, analyzing bioplastic functional groups, and testing biodegradation of bioplastics in soil media. Variations used are avocado seeds used are $0 ; 0.1 ; 0.3 ; 0.5 ; 0.7$; and 1.4 grams. Bioplastic functional group analysis was performed using FTIR. Bioplastic biodegradability in soil media. Bioplastics are $76 \%$ degraded within 12 days in the soil. This shows that bioplastics can be biodegradable.
\end{abstract}

Keywords: Bioplastics, Chitosan, Avocado Seed Starch, Biodegradation biodegradability

\section{INTRODUCTION}

Plastic is one material often used for various storage media. Plastic is the result of the synthesis of petroleum hydrocarbon polymers limited in number and cannot be renewed. Examples of petroleum-based plastics are polypropylene (PP), polycarbonate (PC), polyvinyl chloride (PVC), polyethylene (PE), polystyrene (PS) and others (Pilla, 2011). Plastic has a very complex molecular structure that is difficult to degrade by microorganisms and difficult to renew in a short time (Lazuardi, 2013). Synthesis plastic, in general, is durable and difficult to be destroyed by natural processes so it becomes a problem for the environment. Incomplete combustion of plastic emits harmful dioxin gas to health. The plastic recycling process will also cause new problems related to energy efficiency during the process. The use of plastics as an energy source has not completely solved the existing problems, because the pollutants and residues produced are included in hazardous and toxic waste (Karina, 2015).

One effort to reduce the problem of plastic waste is to make plastic easily degraded or better known as biodegradable bioplastic. Bioplastics are plastics made from materials easily renewed and easily degraded by biological processes (Pilla, 2011). The principle that is the focus of efforts to make bioplastics is the principle of green chemistry. Materials that can be used as bioplastic raw materials include cellulose, starch, collagen, casein, protein or lipids found in animals (Sinaga et al., 2014).

Chitosan is a biomaterial obtained from the deacetylation of chitin derived from shrimp shells with sodium hydroxide. The abundance of chitosan in nature is the second most after cellulose, so chitosan is widely used as a raw material for environmentally friendly products because it is non-toxic and biodegradable
(Khantayanuwong, 2016). The use of chitosan as a raw material for making bioplastics because chitosan can form clear, strong, and flexible layers (Mackay and Tait, 2011). Chitosan-based bioplastic degradation process in the environment tends to be time-consuming, so starches need to be added as an additive. This is because the ability of starch to absorb high water then becomes the optimum place for the growth of several integration microorganisms (Wahyuningtyas and Suryanto, 2017). Starch can be obtained from roots, stems, tubers and seeds (Kabasci, 2014). One source of starch is avocado seeds. Avocado seeds are often found as waste from the sale of fruit juices and the avocado-based food industry. According to research conducted by Macey A. Mahawan (2015), it is known that avocado seeds have an average total carbohydrate amount of 74.65 grams. Abede Reda Wouldu and Yeshitilia Asteraye Tsigie (2015) in Maulida Lubis (2016), said that avocado seed waste has $30 \%$ starch content that can be used as a bioplastic material.

The ability of bioplastics to be degraded in the environment is one of the properties that must be possessed by bioplastics. Bioplastic biodegradation tests have been carried out with various media. Starting from using various types of microorganisms to more complex systems such as compost and seawater (Emadian et al., 2016).

\section{MATERIALS AND METHODS}

\section{Tools and materials}

The tools used in this study include: a set of glassware, thermometer, blender, bioplastic mold, sari paper, soil tester, universal $\mathrm{pH}$ paper, FTIR instrument (Shimadzu Pretige 21), oven (Heraus UT 6120), analytical balance 
(OHAUSUS AR 2140), and a set of universal test machine tools (UTM Zwick/Z0,5).

Materials used in this study include: chitosan obtained from CV Chem-Mix Pratrama, avocado seeds obtained from Nologaten Juice Terminal waste, distilled water, sorbitol and glacial acetic acid obtained from CV ChemMix Pratama.

\section{Making Avocado Seed Starch}

Avocado seeds are first to cut into small pieces and then washed using clean water, after that 100 grams of avocado seeds are added with $100 \mathrm{~mL}$ of water to blend. Avocado seeds that have been blended are then separated between the residue and the filtrate by filtering, then the filtrate from the avocado seeds is deposited for 30 minutes and filtered using a buchner pump, the precipitate obtained is then dried at $60^{\circ} \mathrm{C}$ until it is completely dry. Avocado seed starch formed later on its functional groups were analyzed using FTIR.

\section{Bioplastic Manufacturing}

As much as 4 grams of chitosan were dissolved in a beaker filled with $100 \mathrm{~mL}$ of distilled water and stirred. Furthermore, avocado seed starch is added with variations $(0 ; 0.1 ; 0.3 ; 0.5 ; 0.7$ and 1.4 grams $), 1 \mathrm{~mL}$ glacial acetic acid and sorbitol as much as 3 grams. The mixture is then stirred and heated at $70{ }^{\circ} \mathrm{C}$. The bioplastic gel formed is then printed in a $20 \times 20 \mathrm{~cm}$ mold, then dried and cooled. Bioplastics that are formed are then released from the mold to be analyzed at a later stage.

\section{Biodegradation Test}

The bioplastic is first cut to a size of $3 \times 3 \mathrm{~cm}$ and then weighed and recorded as the initial weight of the bioplastic. Furthermore, bioplastics are buried in containers that have filled the soil for 12 days. Samples are examined every two days to find out changes in weight in bioplastics. Before weighing, bioplastics are first cleaned and dried in an oven at $50^{\circ} \mathrm{C}$.

\section{RESULTS AND DISCUSSION}

\section{Making Avocado Seed Starch}

The process of separating starch from the mixture contained in avocado seeds using a simple extraction method. The principle of simple extraction is to separate, withdraw, or remove a substance from the mixture using a suitable solvent for the desired substance. Avocado seed starch extraction begins with cutting and selecting avocado seeds, the selection of avocado seeds is aimed so that the resulting starch has good quality. Avocado seeds that have been selected are then extracted and dried using an oven to reduce water content, so that it can inhibit bacterial growth and can extend the shelf life (Jabbar, 2017). Starch obtained from 100 grams of avocado seeds is as much as 10 grams.

In the process of cutting avocado seeds, it is observed that the color of the seeds changes from white to brownish red when left in the air. This discoloration is due to avocado seeds containing dopa phenolic compounds (3,4-dihydroxyphenylalanine). These phenolic compounds can cause enzymatic browning caused by the reaction between oxygen and the phenolic substrate with a polyphenol oxidase catalyst. Polyphenol oxidase is an enzyme-containing copper $(\mathrm{Cu})$ which catalyzes the oxidation of phenol compounds. This activity can change the monophenol group into Ohydroxy phenol (diphenol) which is then converted again into O-quinone. O-quinone undergoes non-enzymatic polymerization to produce melanin which is a darkcolored pigment (Queiroz in Afif, 2018). Enzymatic browning reactions are presented in Figure 1.

Avocado seed starch that has been obtained is then identified its functional group using the FTIR spectrophotometer at wavenumbers $4000-400 \mathrm{~cm}^{-1}$. The identification of functional groups of avocado seed starch using the FTIR spectrophotometer aims to prove the starch from avocado seeds has been formed. The results of functional group avocado seed starch identification are presented in the FTIR spectra in Figure 2.
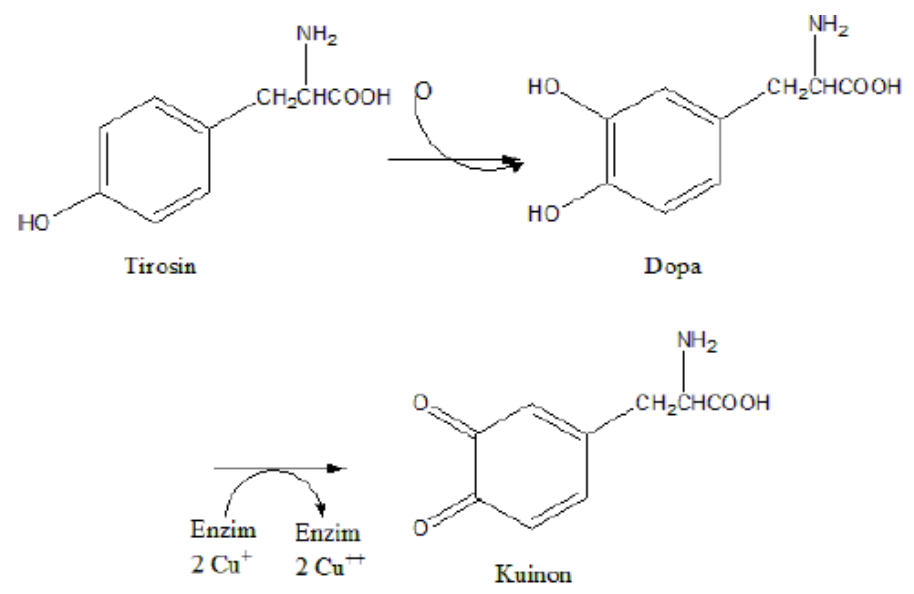

Figure 1. Enzymatic Browning Reaction (Queiroz dkk., 2008). 


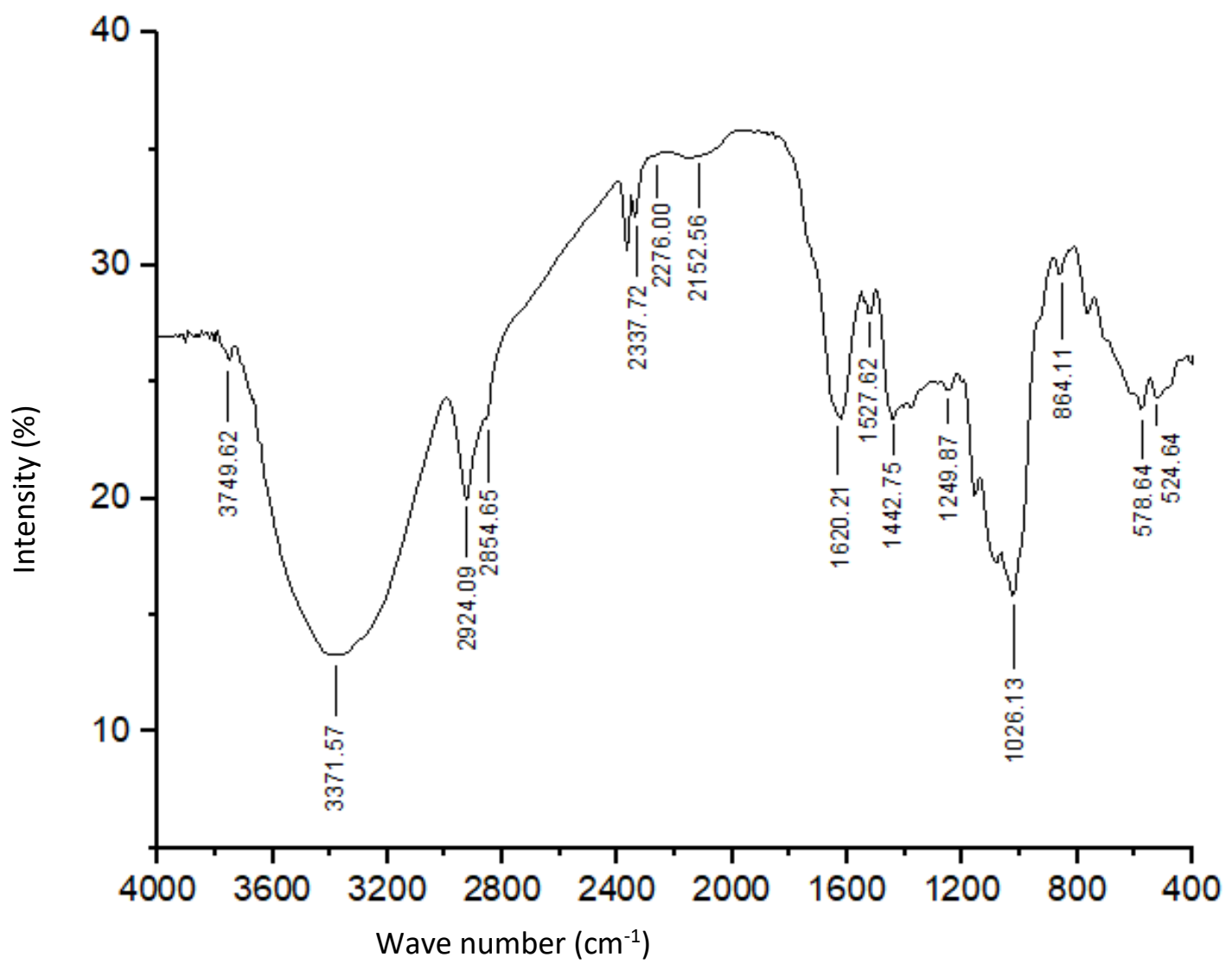

Figure 2. Avocado Fruit Seed FTIR Spectra.

Analysis of starch using FTIR showed a wide absorption at the wave number $33371.57 \mathrm{~cm}^{-1}$ indicating the presence of the $-\mathrm{OH}$ group. Uptake with a fairly sharp intensity at wave number $2924.09 \mathrm{~cm}^{-1}$ indicates the presence of stretching C-H $3000-25050 \mathrm{~cm}^{-1}$. The existence of the $\mathrm{C}-\mathrm{O}$ ether group is known from the appearance of sharp absorption in the region of 1300$1000 \mathrm{~cm}^{-1}$, precisely at wave number $1026.13 \mathrm{~cm}^{-1}$. The appearance of these functional groups represents that avocado seed starch consists of amylose and amylopectin, and glucose reduction (C6H10O5) $n$ (Irwan et al. In Lubis, 2016). Based on the wave number uptake that appears, it can be concluded that the avocado seed starch has been formed.

\section{Bioplastic Manufacturing}

Making chitosan bioplastics uses the blending method, which is a method of combining several bioplastic making materials into one. Chitosan is first dissolved in distilled water until homogeneous. The variation of the addition of avocado seed starch used is $0 ; 0.1 ; 0.3 ; 0.5$; 0.7 ; and 1.4 grams, then sorbitol plasticizer was added to increase bioplastic flexibility (Darni, 2010). The glacial acetic acid solution is added to increase solubility. All materials that have been mixed then the solution is stirred using a magnetic stirrer for 30 minutes at $70^{\circ} \mathrm{C}$ until the solution becomes homogeneous. The resulting bioplastic is a brownish thin film.

\section{Analysis of Bioplastic Function Groups}

Bioplastics that have been formed are then characterized using FTIR. Analysis using FTIR was conducted to determine the functional groups contained in chitosan and bioplastics. FTIR chitosan and bioplastic spectra analysis are presented in Figure 3.

Based on Figure 3 it is known that there is absorption at the wave number $3425.58 \mathrm{~cm}^{-1}$ which indicates the presence of $\mathrm{O}-\mathrm{H}$ groups. $\mathrm{C}-\mathrm{H}$ bonding from chitosan spectra can be found at wave number $2877.79 \mathrm{~cm}^{-1}$. In the wavenumber area $1072.42 \mathrm{~cm}^{-1}$, there is a C-O ether bond. The characteristic of chitosan is the emergence of strong absorption at the wave number $1597.06 \mathrm{~cm}^{-1}$ which indicates there is an $\mathrm{N}-\mathrm{H}$ group. 


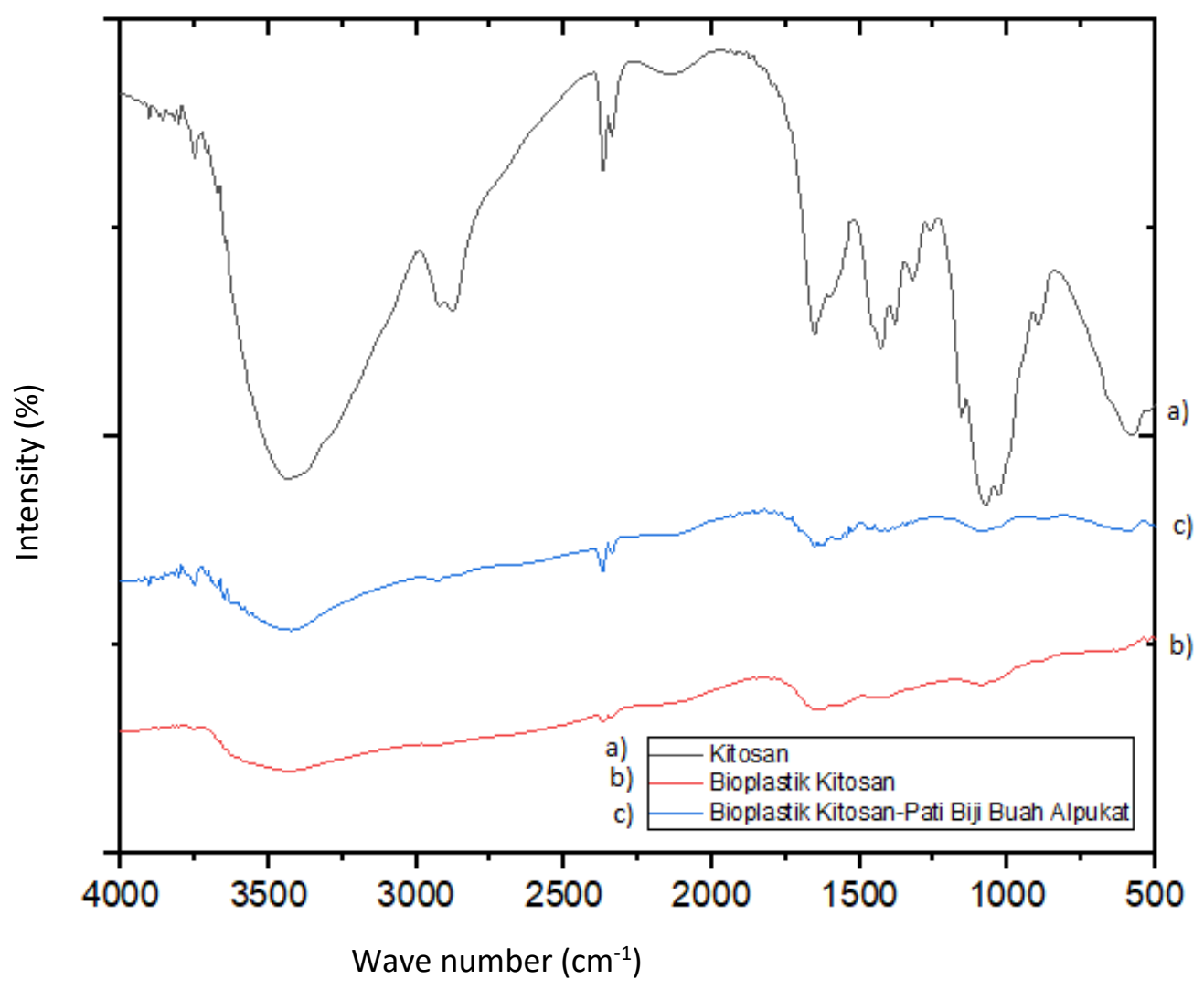

Figure 3. Chitosan FTIR Spectra, Chitosan Bioplastics and Avocado Fruit Seed Chitosan-Starch Bioplastics.

Figure 3 also show the results of the chitosan bioplastic and chitosan bioplastic spectra with the addition of avocado seed starch. In chitosan bioplastics, there are a wavenumber $3425.58 \mathrm{~cm}^{-1}$ which shows the $\mathrm{O}-\mathrm{H}$ group. O-H group on chitosan bioplastic does not change the wave number, but there is a widening of the band and a decrease in the intensity of the wavenumber. This shows that chitosan bioplastics are starting to form. In the $\mathrm{C}-\mathrm{H}$ bond, there is a shift in the wavenumber from $2877.79 \mathrm{~cm}^{-1}$ chitosan to $2924.09 \mathrm{~cm}^{-1}$ in chitosan bioplastics. The wavenumber shift also occurs in the C$\mathrm{O}$ ether bond which is shifted to $1087.85 \mathrm{~cm}^{-1}$. Besides, the N-H group also experienced a shift in the wavenumber from $1597.06 \mathrm{~cm}^{-1}$ chitosan to $1635.64 \mathrm{~cm}^{-}$ ${ }^{1}$ in chitosan bioplastics.

Chitosan bioplastic with the addition of avocado seed starch, there was a shift in the $\mathrm{O}-\mathrm{H}$ functional group, the shift in wavenumber occurred from $3425.58 \mathrm{~cm}^{-1}$ on chitosan bioplastic to $3448.72 \mathrm{~cm}^{-1}$ on the chitosan bioplastic with the addition of avocado seed starch. This wavenumber shift is accompanied by changes in intensity and widening of the $\mathrm{O}-\mathrm{H}$ wave number band. The wavenumber shift also occurs in the $\mathrm{C}-\mathrm{H}$ bond, the wavenumber of the $\mathrm{C}-\mathrm{H}$ bond in the chitosan bioplastic is $2924.09 \mathrm{~cm}^{-1}$ shifted to $2931.80 \mathrm{~cm}^{-1}$ in the chitosan bioplastic by the addition of avocado seed starch. However, the phenomenon of wave number shifting does not occur in $\mathrm{C}-\mathrm{O}$ and $\mathrm{N}-\mathrm{H}$ functional groups, where the wavenumbers of the two functional groups are still at $1087.85 \mathrm{~cm}^{-1}$ and $1635.64 \mathrm{~cm}^{-1}$. The shift of wavenumbers that occur in bioplastic chitosan and bioplastic chitosan with the addition of avocado seed starch indicates the reaction of polymerization of bioplastic materials during blending and also indicates that the interaction that occurs is physical interaction. Physical interaction can also be seen from the absence of new functional group bands that appear in bioplastics (Saputro and Arrum, 2017) both chitosan bioplastics and chitosan bioplastics with the addition of avocado seed starch.

\section{Biodegradation Test}

The bioplastic biodegradation test aims to determine the ability of bioplastics can be decomposed by biological activity in the environment. According to Utami et al. (2014), bioplastics are easily degraded because the constituent components in them are natural materials. The resulting bioplastics contain hydroxyl $(\mathrm{OH})$ and carbonyl (CO) groups. The cluster is what causes bioplastics to be degraded well. In general, the factors that accelerate the process of biodegradation are components of the constituent solution, bacterial activity, polymer structure, morphology, molecular weight, temperature, environment, and humidity (Afif, 2018). 
The bioplastic biodegradation process begins with the attack of bioplastic surfaces by microorganisms. After microorganisms arrive at the bioplastic surface, then the growth of the invading microorganisms occurs with a bioplastic polymer as a carbon source. When the biodegradation process takes place, microorganisms will release extracellular enzymes that can break the polymer chain into small parts like oligomers, dimers and monomers. These parts are used by microorganisms as a source of carbon and energy source (Alshehrei, 2017)

Based on Figure 4 to Figure 9, it can be seen that the bioplastics produced are biodegradable. This can be proven by decreasing the bioplastic mass of each variation in the observation time for 12 days. When seen from the slope value of the bioplastic biodegradation graph linear equation of each variation, it can be seen that the slope values of Figure 5 to Figure 9 have increased, namely from -5.317 on the rise to -6.3622 . This can be interpreted that the increasing variety of avocado seed starch, the resulting bioplastics will be easily degraded in soil media. The degree of biodegradation of the polymer material is affected by the structure of the polymer in question. Amorphous polymers are more easily degraded than crystalline polymers. Because starch is an amorphous structure polymer, the higher the content of starch compounds in a bioplastic mixture, the rate of bioplastic biodegradation will be faster (Daud, 2009).

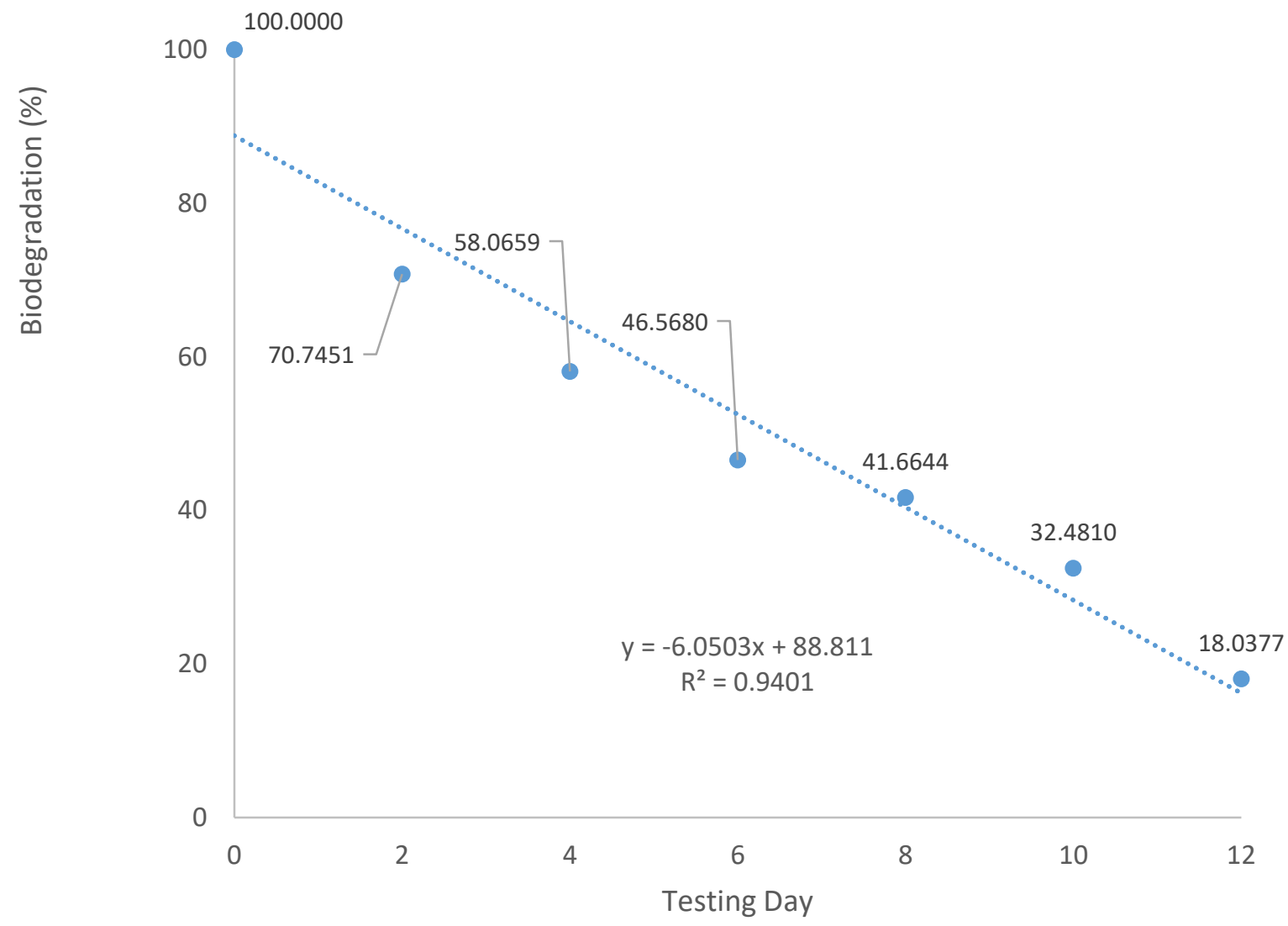

Figure 4. Biodegradation Bioplastic Variation of Avocado Fruit Seed Starch 0 gram. 


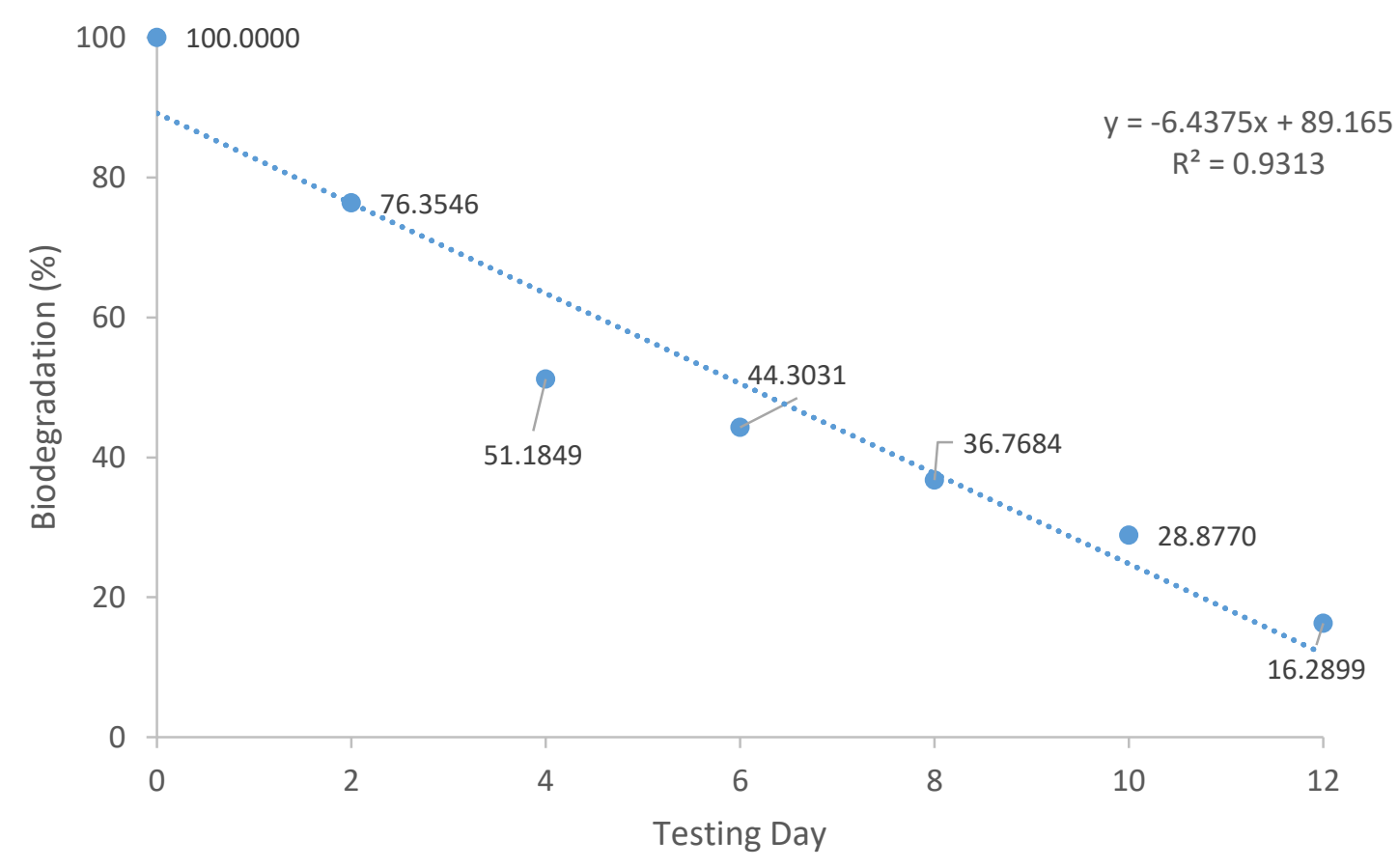

Figure 5. Biodegradation Bioplastic Variation of Avocado Fruit Seed Starch 0,1 gram.

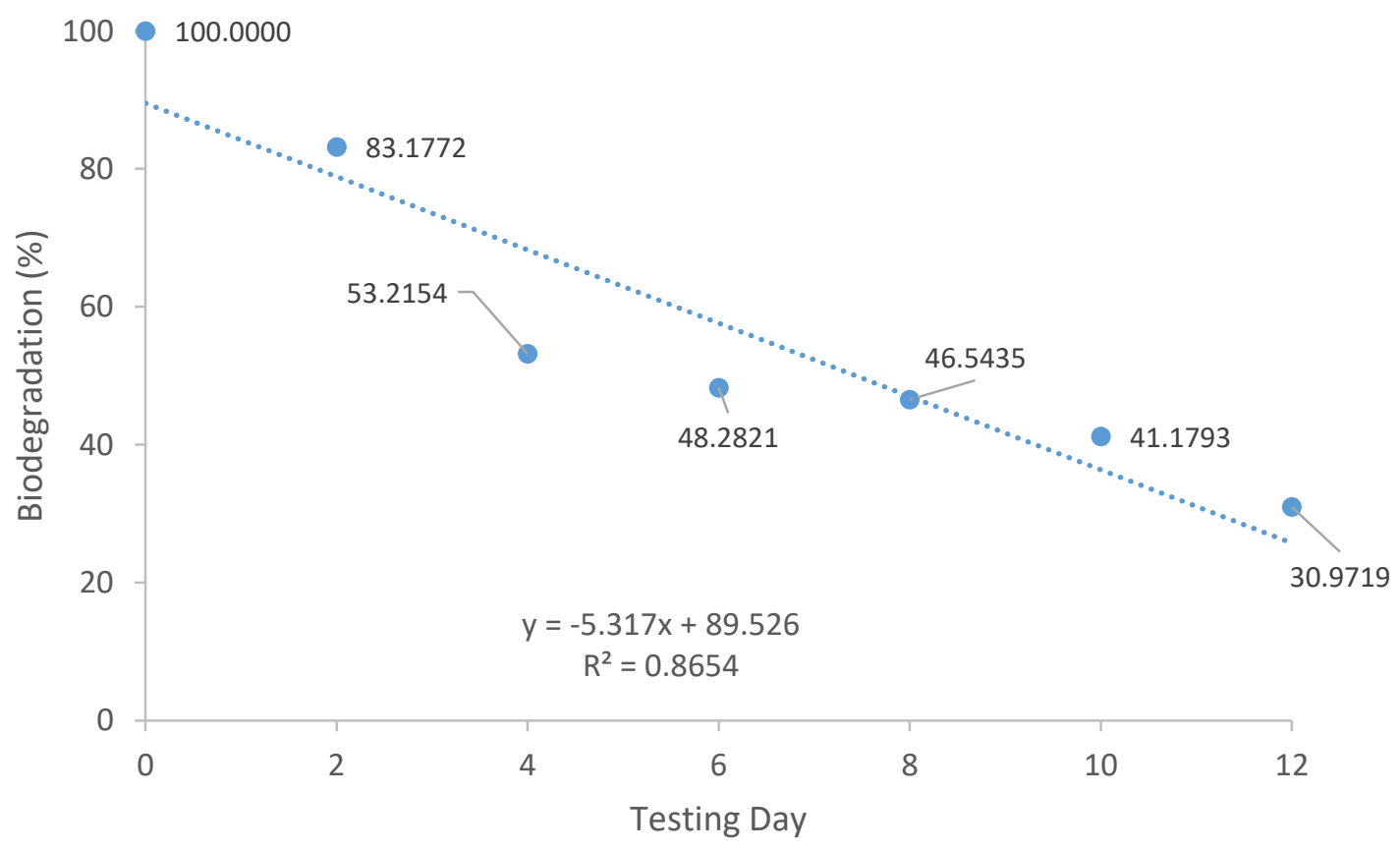

Figure 6. Biodegradation Bioplastic Variation of Avocado Fruit Seed Starch 0,3 gram. 
FATHUROHMAN et al. - The Effect of Addition of Avocado Fruit Seeds On ...

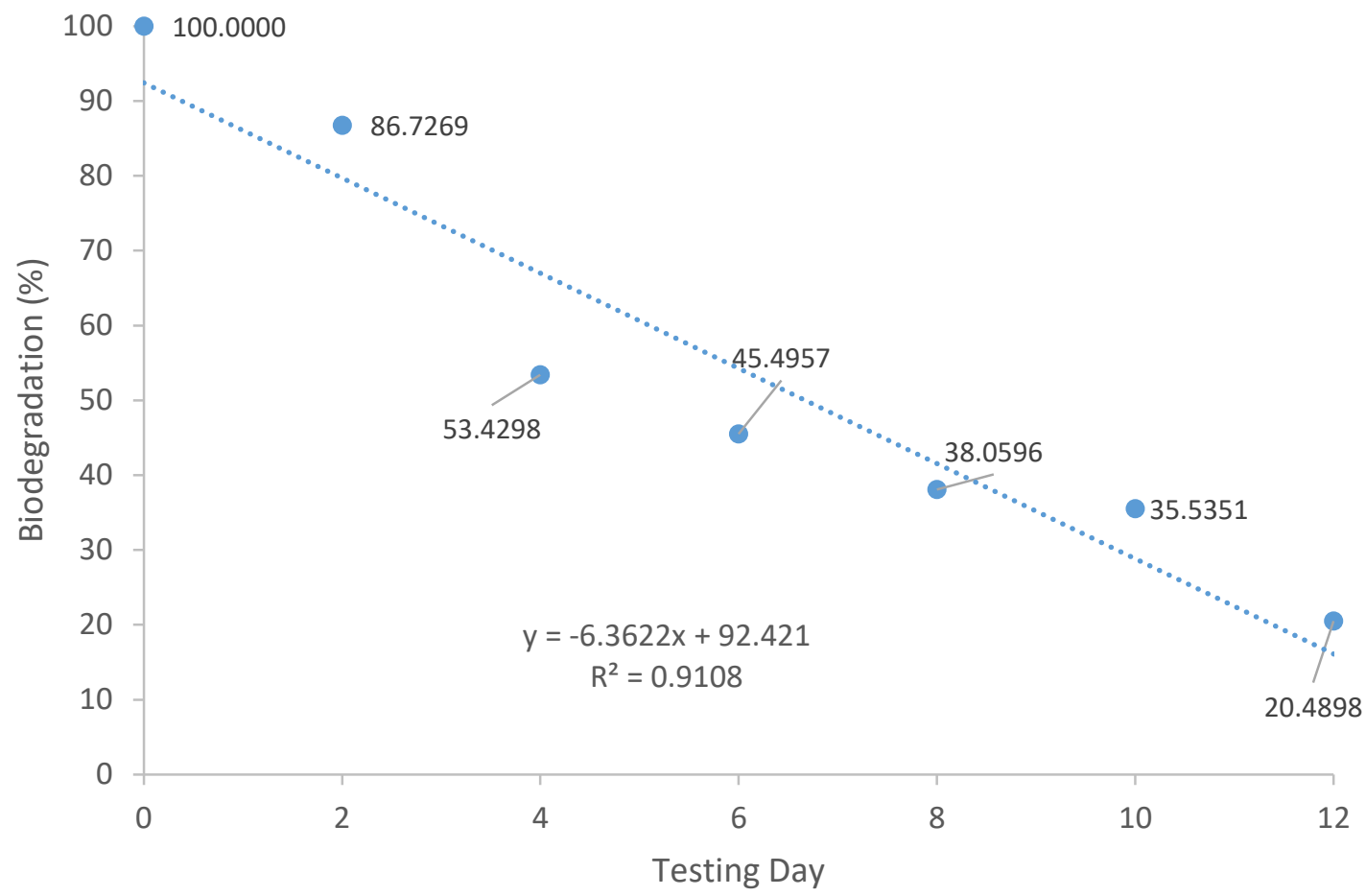

Figure 7. Biodegradation Bioplastic Variation of Avocado Fruit Seed Starch 0,5 gram.

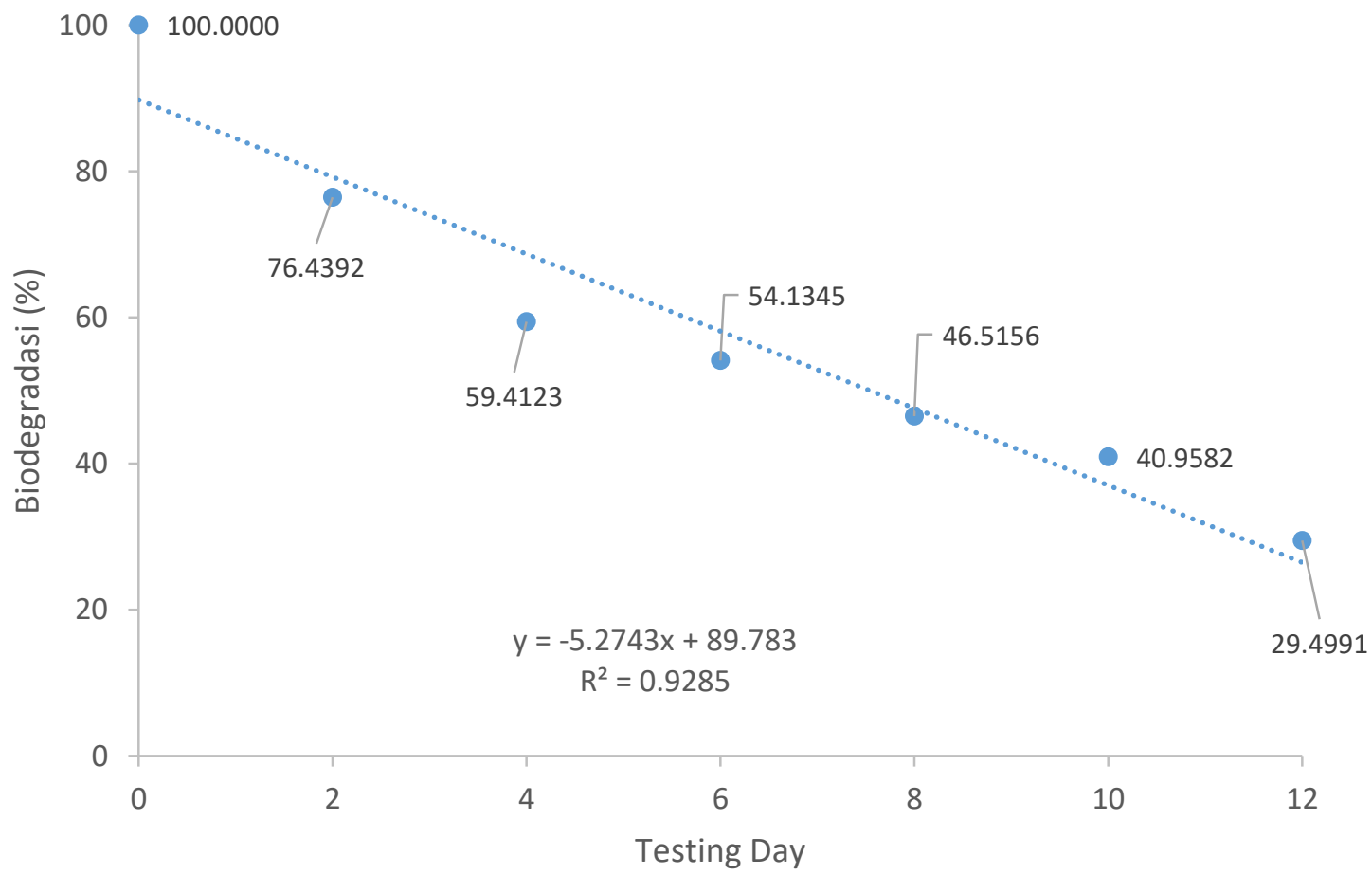

Figure 8. Biodegradation Bioplastic Variation of Avocado Fruit Seed Starch 0,7 gram. 


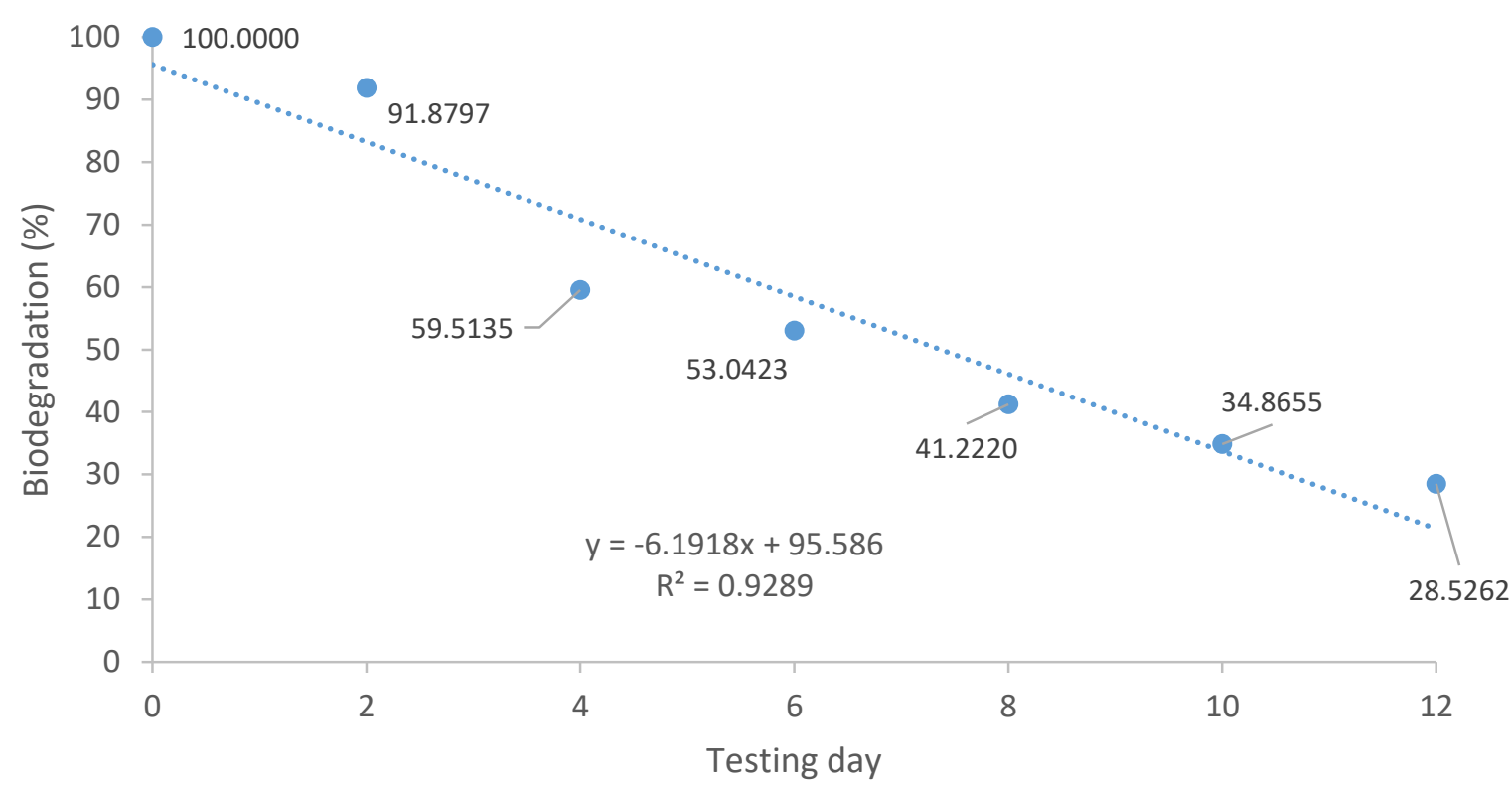

Figure 9. Biodegradation Bioplastic Variation of Avocado Fruit Seed Starch 1,4 gram.

Table 1. Analysis of Bioplastic Biodegradation Variants.

\begin{tabular}{rccc}
\hline & Day 2 & Day 6 & Day 12 \\
\hline Chi-Square & 11,526 & 6,661 & 7,924 \\
df & 5 & 5 & 5 \\
Asymp. Sig. & 0,042 & 0,247 & 0,160 \\
\hline
\end{tabular}

Percent decrease in bioplastic mass was further analyzed using Kruskal-Wallis variance analysis to determine whether there were any differences produced by each bioplastic biodegradation test on the second, sixth, and twelfth days. The results of the analysis of variance can be seen in Table 1 .

On the second day of biodegradation testing, the analysis showed a significant difference. This can be interpreted that variations in the addition of avocado seed starch significantly affect the decrease in bioplastic mass on the second day. However, on the sixth and twelfth days, the results of the analysis did not show any significant differences, meaning that variations in the addition of avocado seed starch did not significantly affect the reduction in bioplastic mass. From the results of the analysis of variance, it can be seen that the effect of variations in the addition of starch to bioplastic biodegradation is only significantly seen on the second day, not on the sixth and twelfth days.

\section{CONCLUSION}

Bioplastics obtained have biodegradable properties. This can be seen from the average decrease in bioplastic weight loss over 12 days by $76 \%$. The addition of avocado seed starch on bioplastics has an insignificant effect on bioplastic biodegradation.

\section{REFERENCES}

Afif, Muhammad, Namik Wijayati dan Sri Mursiti. Pembuatan dan Karakterisasi Bioplastik dari Pati Biji Alpukat-Kitosan dengan Plasticizer Sorbitol. Inonesian Journal of Chemical Science Vo. 7, No. 2.

Alshehrei, Fatimah. 2017. Biodegradation of Synthetic and Natural Plastic by Microorganism. Journal of Applied and Environmental Microbiology, Vol. 5, No. 1.

Daud, Asiah M. 2009. Uji Biodegradasi dari Khitosan Limbah Kulit Udang dan Pati Tapioka. Jurnal Biologi Edukasi, Vol. 2, No. 1.

Darni, Yuli. 2010. Studi Pembuatan dan Karakterisasi Sifat Mekanik dan Hidrofibitas Bioplastik dari Pati Sorgum. Jurnal Rekayasa Kimia dan Lingkungan, Vol. 7, No. 4: 88 - 93.

Emadian, S. Mehdi, Turgut T. Onay dan Burak Demirel. 2016. Biodegradtion of Bioplastic In Natural Environments. Journal Waste Management Vol. 59: 526 - 536.

Jabbar, Uhsunul Fatimah. 2017. Skripsi: Pengaruh Penambahan Kitosan Terhadap Karakteristik Bioplastik dan Pati Kulit Kentang (Solanum tubersom L.). Makassar: UIN Alauddin. 
Kabasci, Stephan. 2014. Bio-Based Plastics Materials and Applications. New Jersey: Wiley.

Karina, Myrtha. 2015. Penelitian dan Pengembangan Plastik Ramah Lingkungan di Indonesia. Bandung: Pusat Penelitian Fisika - LIPI. Prosiding Seminar Nasional Kulit, Karet, dan Plastik ke-4 Yogyakarta.

Khantayanuwong, Somwang, Chutatip Khemarom dan Sumaida Salaemae. 2016. Effects os Shrimp Chitosan on The Physical Properties of Handsheets. Pulp and Paper Technology Program, Department of Forest Products, Faculty of Forestry, Kasetsart University.

Lazuardi, Gilang Pandu dan Sari Edi Cahya Ningrum. 2013. Pembuatan dan Karakterisasi Bioplastik Berbahan Dasar Kitosan dan Pati Singkong dengan Plasticizer Gliserol. Surabaya: Jurusan Kimia, FMIPA, UNESA. Journal of Chemistry, Vol. 2, No. 3: 161 - 166.

Mackay, Richard G., Tait J.M., 2011. Handbook of Chitosan Research and Applications. New York: Nova Science Publisher, Inc.

Mahawan, Macey A., Ma. Francia N. Tenorio dan Jaycel A. Gomez. 2015. Characterization of Flour from Avocado Seed Kernel. Alangilan: Asia Pacific Journal of Multidisciplinary Research, Vol. 3, No. 4: $34-40$.
Pilla, Srikanth. 2011. Handbook of Bioplastics and Biocomposites Engeneering Applications. New Jersey: Wiley.

Queiroz, C. dkk., 2008. Polyphenol Oxidase: Characteristics and Mechanisms of Browning Control. Food Reviews International, Vol; 24, No: 3.

Saputro, Agung Nugroho Catur dan Arruum Linggar Ovita. 2017. Sintesis dan Karakterisasi Bioplastik dari Kitosan-Pati Ganyong (Canna edulis). Jurnal Kimia dan Pendidikan Kimia, Vol. 2, No. 1.

Sinaga, Rinaldi Febrianto dkk. 2014. Pengaruh Penambahan Gliserol Terhadap Sifat Kekuatan Tarik Pemanjangan Saat Putus Bioplastik dari Pati Umbi Talas. Medan: Departemen Teknik Kimia, Fakultas Teknik, Universitas Sumatera Utara. Jurnal Teknik Kimia USU, Vol. 3, No. 2: 19 - 24.

Wahyuningtiyas, Nanang Eko dan Suryanto Heru. 2017. Analysis of Biodegradation of Bioplastics Made of Cassava Starch. Journal of Mechanical Engeneeing Science and Technology Vol. 1, No. 1.

Woldu, Abede Reda dan Yeshitila Asteraye Tsigie. 2015. Optimization of Hydrolysis for Reduced Sugar Determinaton from Avocado Seed Wastes. Ethiopia: American Journal for Environment, Energy, and Power Research, Vol. 3, No. 1: 1 10. 
THIS PAGE INTENTIONALLY LEFT BLANK 